
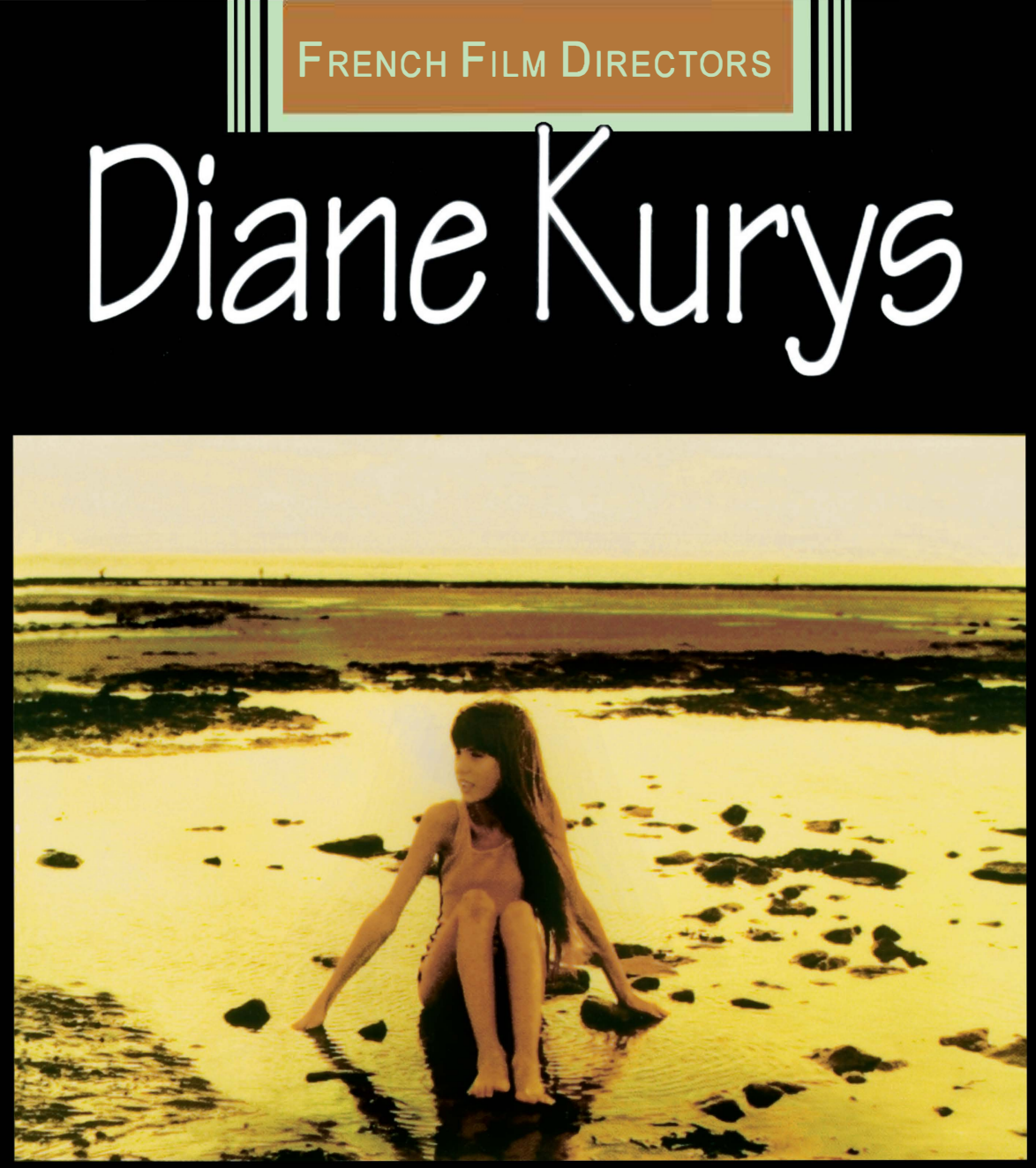

CARRIE TARR 


\section{Diane Kurys}




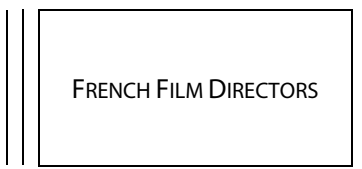

DIANA HOLMES and ROBERT INGRAM series editors DUDLEY ANDREW series consultant 


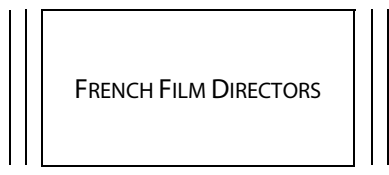

\section{Diane Kurys}

\section{CARrie TARr}

\section{MANCHESTER 1824}

Manchester University Press 


\section{Copyright (C) Carrie Tarr 1999}

The right of Carrie Tarr to be identified as the author of this work has been asserted by her in accordance with the Copyright, Designs and Patents Act 1988.

Published by Manchester University Press

Altrincham Street, Manchester M1 7JA, UK

www.manchesteruniversitypress.co.uk

British Library Cataloguing-in-Publication Data

A catalogue record for this book is available from the British Library

Library of Congress Cataloging-in-Publication Data

A catalog record for this book is available from the Library of Congress

ISBN 0719050952 paperback

ISBN 13: 9780719050954

First edition published 1999 by Manchester University Press

The publisher has no responsibility for the persistence or accuracy of URLs for any external or third-party internet websites referred to in this book, and does not guarantee that any content on such websites is, or will remain, accurate or appropriate. 